\title{
Long Term Impact of Conjugate Vaccines on Haemophilus influenzae Meningitis: Narrative Review
}

\author{
Mary Paulina Elizabeth Slack
}

check for

updates

Citation: Slack, M.P.E. Long Term Impact of Conjugate Vaccines on Haemophilus influenzae Meningitis: Narrative Review. Microorganisms 2021, 9, 886. https://doi.org/ $10.3390 /$ microorganisms 9050886

Academic Editor: James Stuart

Received: 17 March 2021

Accepted: 19 April 2021

Published: 21 April 2021

Publisher's Note: MDPI stays neutral with regard to jurisdictional claims in published maps and institutional affiliations.

Copyright: (C) 2021 by the author. Licensee MDPI, Basel, Switzerland. This article is an open access article distributed under the terms and conditions of the Creative Commons Attribution (CC BY) license (https:/ / creativecommons.org/licenses/by/ $4.0 /)$.
Gold Coast Campus, School of Medicine \& Dentistry, Griffith University, Southport, QLD 4222, Australia; m.slack@griffith.edu.au

\begin{abstract}
H. influenzae serotype b (Hib) used to be the commonest cause of bacterial meningitis in young children. The widespread use of Hib conjugate vaccine has profoundly altered the epidemiology of $H$. influenzae meningitis. This short review reports on the spectrum of $H$. influenzae meningitis thirty years after Hib conjugate vaccine was first introduced into a National Immunization Program (NIP). Hib meningitis is now uncommon, but meningitis caused by other capsulated serotypes of $H$. influenzae and non-typeable strains (NTHi) should be considered. H. influenzae serotype a (Hia) has emerged as a significant cause of meningitis in Indigenous children in North America, which may necessitate a Hia conjugate vaccine. Cases of Hie, Hif, and NTHi meningitis are predominantly seen in young children and less common in older age groups. This short review reports on the spectrum of $H$. influenzae meningitis thirty years after Hib conjugate vaccine was first introduced into a NIP.
\end{abstract}

Keywords: Haemophilus influenzae; Hib; impact of Hib conjugate vaccine; Hia; NTHi

\section{Introduction}

Haemophilus influenzae is a small, pleiomorphic Gram-negative coccobacillus, which is restricted to humans. It is fastidious in its growth requirement, only growing in culture media supplemented with both $\mathrm{X}$ factor (hemin) and $\mathrm{V}$ factor (nicotinamide adenine dinucleotide, NAD), for example chocolate agar. $H$. influenzae strains can be differentiated into two major groups: capsulated and non-capsulated strains (generally referred to as non-typeable strains, NTHi). The capsulated strains are further divided into six groups (a to f) based on the chemical structure of their polysaccharide capsules [1]. The most virulent type of $H$. influenzae is type $b(\mathrm{Hib})$ and the major virulence determinant of Hib is its polysaccharide capsule, composed of polyribosyl ribitol phosphate (PRP).

H. influenzae colonizes the nasopharynx [2] and to a lesser extent the conjunctivae [3] and genital tract [4-6]. The respiratory tract is mainly colonized by H. influenzae and to a lesser extent $H$. parainfluenzae [2]. Approximately $80 \%$ of individuals carry NTHi strains in the nasopharynx, while $3-5 \%$ carry capsulated strains in the upper respiratory tract $[7,8]$. Spread from one person to another occurs via respiratory droplets or by direct contact with secretions [4].

Before the introduction of Hib conjugate vaccines, Hib was the commonest cause of bacterial meningitis in young children in the United States [9,10], Sweden [11], Iceland [12], the Netherlands [13], and England and Wales [14]. Seventy five percent of Hib meningitis cases occurred in children between the ages of three months and three years $[15,16]$. The case fatality ratio of Hib meningitis was $\sim 5$ to $10 \%$ in high-income countries [17].

In 1933, Fothergill and Wright [18] reported that blood from children aged less than two years lacked bactericidal activity against Hib, whereas blood from older children and adults demonstrated bactericidal activity. They speculated that naturally acquired antibodies to Hib were protective and as the mean level of Hib antibodies increased through exposure to the organism, so Hib meningitis incidence declined. The paucity of cases of $\mathrm{Hib}$ meningitis in infants aged <two months correlates with the presence of maternal Hib antibodies. This was confirmed by Peltola et al. [19] who demonstrated the incidence of 
Hib meningitis declined as the mean level of anti-Hib antibodies increased. Studies on un-immunized individuals established a putative short-term correlate of protection against Hib infection of $\geq 0.15 \mu \mathrm{g} / \mathrm{mL}$ anti-PRP antibodies [20]. Later studies established that an anti-PRP antibody titer of $\geq 1.0 \mu \mathrm{g} / \mathrm{mL}$ was required for long-term protection [21].

It is now more than three decades since Hib conjugate vaccines were first developed and a variety of vaccine formulations, with a Hib component, are now included in the NIP of almost all countries in the world. Wherever Hib conjugate vaccine has been used the epidemiology of $H$. influenzae meningitis has changed, with Hib meningitis now infrequently seen in young children [22]. However, H. influenzae serotype a (Hia) has emerged as a significant cause of meningitis in Indigenous children in North America [23], and nontypeable strains of $H$. influenzae (NTHi) are associated with invasive infections, including meningitis, in neonates, older adults, and other vulnerable patient groups [24]. In 2020, the World Health Organization (WHO) published the document" Defeating meningitis by 2030: a global road map" [25]. The aims of the road map include the reduction of cases and deaths from vaccine-preventable meningitis; introduction of new vaccines; increasing vaccine coverage; and improving surveillance and advocacy. This short review will review the current epidemiology of $\mathrm{H}$. influenzae meningitis in the second decade of the twenty first century to assess the progress made to date in achieving the goals set out in this document.

\section{Method}

A PubMed search was performed to identify published papers on the epidemiology of $H$. influenzae meningitis, before and after the introduction of Hib conjugate vaccines, using the terms: (((invasive) AND haemophilus) AND influenzae) AND ("meningitis" OR "nontypable" OR "NTHi" OR "serotype a" OR "serotype b" OR "serotype c" OR "serotype d" OR "serotype e" OR "serotype f" OR "non-b" OR "Hib") AND (epidemiology OR "burden" OR "risk factor" OR "impact" OR "Hib vaccine" OR "Hib conjugate vaccine" OR "surveillance" OR "review" OR "clinical" OR "outcome" OR "neonate" OR "adult" OR "children") for papers published between 1985 and 2020. Relevant papers on H. influenzae meningitis were reviewed.

\section{Global Burden of Hib Meningitis before the Introduction of Routine Hib Immunization}

Acute meningitis was the most serious presentation of Hib infection, following invasion of the blood stream. Often the child initially developed upper respiratory tract symptoms or otitis media before signs of meningeal involvement [4]. Before the introduction of Hib conjugate vaccines, $H$. influenzae serotype $b$ (Hib) was the commonest cause of bacterial meningitis in young children in the US [9], Sweden [11], Iceland [12], the Netherlands [13], and the UK [14]. The mean annual incidence of Hib meningitis in the US was 54/100,000 (range 19-69/100,000) in children aged < five years and 120 to $130 / 100,000$ in infants aged $<12$ months [26]. Annual rates in Europe, Australia (nonIndigenous children) and South America ranged from $<20$ to 50/100,000 children aged $<5$ years [17]. A much higher rate was reported from The Gambia $(60 / 100,000<5$ years and $297 / 100,000<$ one year of age) [27]. Incidence rates of 282/100,000, 254/100,000, $152 / 100,000$, and 450/100,000 in children aged < five years were reported in Alaska Native [28], White Mountain Apache [29], Navajo Indian [30], and Indigenous Australian [31] children, respectively. A rate of 530/100,000 in children aged <five years was reported in the Keewatin District of Northern Canada, mostly afflicting Inuit children [32].

The majority of cases of Hib meningitis cases occurred in children aged between three months and three years $[15,16]$. The proportion varied in different parts of the world, with approximately $50 \%, 40 \%$, and $80 \%$ of cases of Hib meningitis occurring in infants aged $<12$ months in the US, Europe, and Africa, respectively [17]. In the US and Europe, the peak incidence occurred at eight to nine months of age with less than $10 \%$ of cases occurring before the age of six months, and approximately $40 \%$ of all cases of $\mathrm{Hib}$ meningitis occurred in the first year of life [33]. In Indigenous communities in North America and Australia, and in low and middle income countries (LMICs), the proportion 
of cases of Hib meningitis occurring in the first six months of life was higher than in industrialized communities [33]. In Australia, the median age of onset of Hib meningitis (and the proportion of cases in the first 12 months of life) in Indigenous and non-Indigenous children was six months (60\%) and 15 months (17\%), respectively [34]. In The Gambia, 44\% and $84 \%$ of cases occurred in the first six and twelve months of life respectively [33]. In Alaska Native children, $34 \%$ and $67 \%$ of cases of Hib meningitis occurred in the first six and twelve respectively [27] (Table 1).

Table 1. Incidence of Hib meningitis before the introduction of routine Hib conjugate vaccination.

\begin{tabular}{cc}
\hline Region & Hib Meningitis (Cases/100,000 Children < 5 Years of Age) \\
\hline USA & 54 \\
North America (Indigenous) & $152-530$ \\
Europe & $23-31$ \\
Israel & 18 \\
The Gambia & 60 \\
Australia and New Zealand (non-Indigenous) & $25-34$ \\
Australia and New Zealand (Indigenous) & 450 \\
Latin America & 35 \\
Asia & 25 \\
Mongolia & 28 \\
\hline
\end{tabular}

Data derived from: USA [9,10]; North American (Indigenous) [28-30,35]; Europe [36-40]; Israel [41]; The Gambia (Reference [27]; Australia and New Zealand (non-Indigenous) [34,42]; Australia and New Zealand [31,43]; Latin America [44]; Asia [45]; and Mongolia [46].

The mean case fatality ratio (CFR) of Hib meningitis ranged from approximately five to ten $\%$ in high-income countries to $28 \%$ in Africa [17]. Fifteen to $30 \%$ of survivors had long-term sequelae, including sensorineural hearing loss, intellectual impairment, epilepsy, cerebral palsy, or hydrocephalus [26,47-50]. Thirty eight percent of children who survived an episode of Hib meningitis in The Gambia had long-term sequelae [51].

\section{Hib Vaccines}

\subsection{Plain PRP Vaccine}

The first Hib vaccine was a plain polysaccharide vaccine consisting of PRP. It was used in a large field trial in Finland involving 100,000 children aged three months to five years [52]. Although efficacious in children $>18$ months, it did not induce protective levels of anti-PRP antibodies in children aged $<18$ months, i.e., those most at risk of Hib meningitis $[20,53]$. It also failed to have any impact on nasopharyngeal carriage of Hib and so had no impact on transmission [52]. Plain polysaccharide vaccines activate B cells via a T-cell independent pathway, which is poorly developed in children $<18$ months of age [54]. The antibody response is short-lived, mainly IgM with little isotype switching and no induction of immune memory [55].

\subsection{Hib Protein-Conjugate Vaccines}

In the late 1980s conjugate Hib vaccines were developed in which PRP was covalently linked to a protein carrier. The PRP-protein conjugate induces a T-cell dependent response, which develops at a much younger age in infants, who are able to respond to conjugate vaccines from the age of six to eight weeks [56]. The protein antigen encourages class switching from IgM to IgG via T-helper cells [55]. The IgG generated is predominantly IgG1, which in vitro induces complement-mediated opsonization and bacteriolysis. The antibodies produced are of a higher avidity than those produced by a plain polysaccharide vaccine [55]. Furthermore, PRP-conjugate vaccines have a marked impact on nasopharyngeal carriage of Hib [57]. By reducing nasopharyngeal carriage, transmission of Hib to other susceptible children and adults is interrupted, thereby reducing infection in other non-immunized groups. This is called "herd effect" or "herd protection". 
Four different protein carriers were initially used for Hib conjugate vaccines: tetanus toxoid (PRP-TT), diphtheria toxoid (PRP-D), a non-toxic mutant Corynebacterium diphtheriae protein CRM 197 (PRP-CRM) and an outer membrane complex of Neisseria meningitidis (PRP-OMP) [58]. The different Hib vaccines were equally immunogenic in adults but elicited different responses in infants $<18$ months of age. PRP-D was the least immunogenic, generating antibody titers of $\geq 1.0 \mu \mathrm{g} / \mathrm{mL}$ in approximately $30 \%$ of infants after two or three doses [59]. This vaccine was subsequently withdrawn. PRP-OMP vaccine generated antibody titers $\geq 1.0 \mu \mathrm{g} / \mathrm{mL}$ in $70-80 \%$ of infants at two months of age [60] and was the preferred vaccine for use in Indigenous populations in North America and Australia, where there was a very high burden of disease in very young infants [60]. The PRP-TT and PRP-CRM vaccines were similar in their immunogenicity eliciting antibody titers $\geq 1.0 \mu \mathrm{g} / \mathrm{mL}$ after three priming doses [61]. Over time monovalent Hib conjugate vaccines have largely been replaced by combination vaccines, including a bivalent $\mathrm{Hib}+$ meningococcus serogroup $\mathrm{C}$ vaccine (Hib-MenC), and pentavalent and hexavalent vaccines, where Hib is combined with diphtheria toxoid (D), tetanus toxoid (T), pertussis whole cell $(\mathrm{wP})$ or acellular $(\mathrm{aP})$, and/or hepatitis $\mathrm{B}(\mathrm{HepB})$, and/ or inactivated polio vaccine (IPV).

\section{Introduction of Hib Conjugate Vaccine in National Immunization Programs (NIPs)}

Hib vaccine was introduced into the NIP of Finland in 1986 [52], followed by the US in 1987 [62]. In the early 1990s Hib vaccine was added to the NIP in many Western European countries. By 2004, Hib vaccine had been included in the NIP of all European countries and $\geq 90 \%$ high-income countries. The introduction of Hib vaccine into the NIP of LMICs has taken longer, because of several factors. These include a lack of local data on the burden of Hib disease as a result of the difficulties in culturing this fastidious organism, widespread use of antibiotics before collection of blood and cerebro-spinal fluid (CSF) samples for culture and the relatively high cost of the vaccine. In $2004 \mathrm{WHO}$ and the Global Alliance for Vaccines and Immunization (GAVI) sought to address this. Vaccine probe studies [63], in which a randomized controlled trial assesses the difference in incidence of meningitis between children immunized with Hib vaccine and unimmunized children, and the Hib Rapid Assessment Tool (HibRAT) [64] provided data on the burden of Hib meningitis for many LMICs. In 2005, GAVI established the Hib Initiative to accelerate the introduction of $\mathrm{Hib}$ vaccine in GAVI-eligible countries [65]. In 2006, WHO recommended the use of Hib conjugate vaccines in all countries [66], thereby allowing GAVI-eligible countries to apply for Hib vaccine without the need to have local data on Hib disease burden. With these measures, the number of countries using Hib vaccine increased from 89/193 (46\%) in 2004 to $158 / 193(82 \%)$ in 2009 [67]. Hib vaccine has now been added to the NIP of all countries in the world, except China, where it is available in the private market and in the Russian Federation, where it is recommended for certain groups of children [68].

\section{Impact of Hib Conjugate Vaccine on Hib Meningitis}

Wherever Hib vaccine has been introduced there has been a significant and sustained decline in Hib meningitis [69-71]. In 2000, the global incidence of Hib meningitis was estimated to be 31 (uncertainty range (UR) 16-39) cases /100,000 children aged < five years [72]. The estimated incidence varied considerably by region (Table 2). At that time, the only regions that had widespread use of $\mathrm{Hib}$ vaccine were the Americas and Europe. A further analysis of the burden of Hib meningitis in 2000-2015 [73] estimated the global incidence of Hib meningitis had declined to five (UR 2-8) cases/100,000 children aged < five years. There were still regional variations, with the highest estimated incidences in the South East Asian and Western Pacific Regions, which may reflect the lack of introduction of Hib vaccine into some countries in these regions at that time. 
Table 2. Estimated incidence and case fatality ratio of Hib meningitis (with uncertainty estimates) by WHO region in 2000 and 2015.

\begin{tabular}{|c|c|c|c|c|c|c|c|}
\hline & Global & $\begin{array}{l}\text { African } \\
\text { Region }\end{array}$ & $\begin{array}{c}\text { Region of the } \\
\text { Americas }\end{array}$ & $\begin{array}{l}\text { Eastern } \\
\text { Mediter- } \\
\text { ranean } \\
\text { Region }\end{array}$ & $\begin{array}{c}\text { European } \\
\text { Region }\end{array}$ & $\begin{array}{c}\text { South East } \\
\text { Asia } \\
\text { Region }\end{array}$ & $\begin{array}{c}\text { Western } \\
\text { Pacific Region }\end{array}$ \\
\hline $\begin{array}{l}2000 \text { Estimates } \\
\text { Incidence } \\
\text { CFR }\end{array}$ & $\begin{array}{c}31(16-39) \\
43 \%(23-55 \%)\end{array}$ & $\begin{array}{c}46(31-52) \\
67 \%(44-75 \%)\end{array}$ & $\begin{array}{c}25(16-30) \\
28 \%(15-36 \%)\end{array}$ & $\begin{array}{c}24(14-35) \\
44 \%(26-62 \%)\end{array}$ & $\begin{array}{c}16(12-22) \\
27 \%(17-41 \%)\end{array}$ & $\begin{array}{c}27(11-38) \\
44 \%(17-62 \%)\end{array}$ & $\begin{array}{c}34(12-48) \\
22 \%(8-34 \%)\end{array}$ \\
\hline $\begin{array}{c}2015 \text { Estimates } \\
\text { [73] } \\
\text { Incidence } \\
\text { CFR }\end{array}$ & $\begin{array}{c}5(2-8) \\
19 \%(7-29 \%)\end{array}$ & $\begin{array}{c}2(1-3) \\
61 \%(20-98 \%)\end{array}$ & $\begin{array}{c}0(0-0) \\
30 \%(7-51 \%)\end{array}$ & $\begin{array}{c}1(0-1) \\
54 \%(16-89 \%)\end{array}$ & $\begin{array}{c}3(1-5) \\
5 \%(2-9 \%)\end{array}$ & $\begin{array}{c}8(3-12) \\
32 \%(12-49 \%)\end{array}$ & $\begin{array}{c}11(6-18) \\
5 \%(2-8 \%)\end{array}$ \\
\hline
\end{tabular}

Data are estimates (uncertainty range) Incidence is $/ 100,000$ children aged $<5$ years. CFR: case fatality ratio. Data derived from: Watt et al. [61] and Wahl et al. [62].

By 2015, the burden of Hib meningitis was limited to a small number of countries that had not yet or only recently introduced Hib vaccine in their NIP. In the six years since this study almost all countries have now introduced Hib vaccine and the global burden will have been further reduced. This excellent control depends on maintaining high coverage of Hib vaccine combined with on-going surveillance of all cases of Hib meningitis in all ages of patients.

The estimated global CFR of Hib meningitis in 2000 was $43 \%$ (UR 23-55\%), ranging from 22\% (8-34\%) in the Western Pacific Region to 67\% (44-75\%) in the African Region [72]. By 2015, the global CFR had declined to 19\% (7-29\%), ranging from 5\% (2-8) in Europe and the Western Pacific Region to 61\% (20-98\%) in the African Region [73].

In 2013, a systematic review of the impact of Hib conjugate vaccine on childhood meningitis mortality, estimated the dose-specific impact (one dose: relative risk, $\mathrm{RR}=0.64$, 95\% CI 0.38-1.06; two doses; $\mathrm{RR}=0.09,95 \%$ CI 0.03-0.27; three doses: $\mathrm{RR}=0.06,95 \% \mathrm{CI}$ $0.02-0.22$ [ [74]. The relative risk (RR) or risk ratio is the ratio of the probability of meningitis in children vaccinated with Hib vaccine to the probability of meningitis in unvaccinated children. This review estimated that three doses of Hib vaccine would prevent $38-43 \%$ of childhood meningitis mortality [74].

After the introduction of Hib immunization into several NIPs in the 1990s, the incidence of Hib meningitis declined rapidly [26]. Hib conjugate vaccines have proved to be highly effective in all countries, where there is sustained high coverage of the vaccine [75]. In the US active surveillance of invasive $H$. influenzae disease is undertaken in the Active Bacterial Core Surveillance (ABC) sites, coordinated by the Centers for Disease Control and Prevention (CDC). This surveillance system covers a population of over 42 million in five states and five metropolitan areas across the US [76]. In the 1990s, the rate of bacterial meningitis declined by $55 \%$ in the USA following Hib vaccine introduction [77]. Between 1998 and 2007, there were 187 cases of $H$. influenzae meningitis cases identified in the CDC ABC surveillance sites, $9.4 \%$ of cases were due to Hib. The overall incidence of $H$. influenzae meningitis declined between 1998-1999 and 2006-2007, from 0.12/100,000 population ( $95 \%$ CI, 0.09 to 0.17 ) to $0.08 / 100,000$ (95\% CI, 0.05 to 0.11 ) [77]. In 2018, only 38 cases of invasive Hib infection in children aged < five years (incidence $0.19 / 100,000$ ) were notified throughout the US [78].The number of cases of Hib meningitis was not specified.

In a population-based observational study in Finland, where Hib conjugate vaccine was introduced in 1986, there were 1361 reported cases of bacterial meningitis between 1995 and 2014. Four percent of cases were caused by H. influenzae (incidence $0.06 / 100,000$ population) and $92 \%$ of the isolates were non-b [79].The median age of H. influenzae meningitis was 29 years. From 2004 to 2014 two of $26 \mathrm{H}$. influenzae isolates were Hib [79].

Hib meningitis incidence declined by $72-83 \%$ at sentinel hospitals in Pakistan and Bangladesh, respectively, within two years of implementing nationwide Hib conjugate vaccination [80]. In a hospital-based multi-center prospective survey of bacterial meningitis in Turkey from 2015 to 2018, 994 cases of suspected bacterial meningitis in children, aged 
one month to 18 years, were identified [81]. Three (2.4\%) of the 125 culture-positive cases were caused by Hib. Hib conjugate vaccine was introduced in the Japanese NIP in 2013, although Hib vaccine had been available on a voluntary basis since 2008 . A nationwide population-based surveillance of invasive $H$. influenzae diseases in children in Japan [82] identified 336 cases of H. influenzae meningitis between 2008 and 2017. Between 2008-2012 and 2013-2017 there were 336 and 6 cases of $H$. influenzae meningitis, respectively. No cases of invasive Hib meningitis have been identified since 2014.

Although Hib meningitis has been virtually eliminated in almost all countries with established immunization programs and high vaccine coverage, there have been a few examples of countries that have experienced a re-emergence of invasive Hib infections, including Hib meningitis.

\section{Resurgence of Hib Meningitis in Some Countries}

\subsection{Resurgence of Hib in the UK}

In the UK there was a resurgence in cases in the late 1990s. The UK introduced Hib vaccine in 1992 as a three-dose infant schedule of PRP-TT (at two, three, and four months) with no booster dose in the second year of life, together with a catch-up campaign for all children <five years of age. Hib infections declined rapidly in all age groups through direct and indirect (herd) protection. The incidence of invasive Hib disease in England and Wales declined from 22.9/100,000 children < five years in 1990 to 0.65/ 100,000 in 1998 [83]. From $1999 \mathrm{Hib}$ infections began to increase, especially among toddlers, most of whom were fully immunized. After 1999, the incidence of Hib disease increased to 4.6/100,000 in children aged < five years [84], with many of the infections, including meningitis, occurring in toddlers [55]. Studies established that there was a greater than expected decline in Hib antibodies after primary immunization, which had been initially masked by the catchup campaign [85-87]. The catch-up campaign also contributed to indirect protection by reducing nasopharyngeal carriage. By 1998, all children aged < five years had received three priming doses of Hib vaccine in infancy. A single dose of Hib vaccine administered at the age of 12 months was more immunogenic than three doses given in infancy. Another factor was the use of a less immunogenic Hib combination vaccine with diphtheria, tetanus, and acellular pertussis (DTaP-Hib) in 2000-2001 [84,88]. The resurgence was controlled by the re-introduction of a whole-cell pertussis-containing Hib vaccine (DTwP-Hib) in 2002, an Hib booster campaign for toddlers in 2003, and the introduction of a routine 12-month Hib booster in 2006 [89,90].

Since that time Hib infections, including meningitis, have remained at a very low level in the UK, A review of invasive Hib infections in England and Wales, between 2009 and 2012, identified only 14 cases in 2012 [22]. Hib incidence was 0.06/100,000 (two cases) in children aged <five years [22]. Most of the cases that occurred over those four years were in adults $(73 \%)$, many of whom had underlying comorbidities and presented with pneumonia (56\%) [22]. The Hib-associated case fatality rate was $9.4 \%(10 / 106$ cases) [22]. There were 20 cases $(18.9 \%)$ of meningitis: ten in children aged < one year; five in children aged one to five years, two in adults aged 20 to 44 years, two in adults aged 45 to 64 years and one case in an older adult aged $\geq 65$ years [22]. There was only one death in the vaccine-eligible age cohort: a child with Hib meningitis who was partially vaccinated and had a complement deficiency [22]. Hib meningitis is now uncommon in the UK.

The current Hib vaccination program in the UK is hexavalent vaccine (DTaP-HibHepB-IPV) administered at two, three, and four months, with a 12-month booster dose of Hib-MenC vaccine [91]. The number of cases of invasive Hib infection is at a very low level, with only five cases of invasive Hib disease (cases that were meningitis not specified) in the vaccine eligible population in 2017-2018 [92].

\subsection{Resurgence of Hib in South Africa}

South Africa introduced Hib conjugate vaccine (PRP-TT) in 1999 as an early accelerated schedule of three doses at six, ten, and fourteen weeks without a booster dose in the second 
year of life [93]. The number of cases of invasive Hib infection initially declined, but from 2005 increasing number of cases in fully vaccinated children were detected [94]. Despite high vaccination coverage the detection rate of invasive Hib infection in children aged < five years increased from $0.7 / 100,000$ in 2003 to 1.3/100,000 in $2009(p<0.001)$, and $135 / 263(51 \%)$ of cases in children with known vaccination status were Hib vaccine failures [93]. From 2003 to 2009 the surveillance program (GERMS) identified 349 cases of invasive Hib infection in children aged <five years, of which $211(60 \%)$ presented as meningitis [94] with a CFR of $19 \%$. Fifty-five $\%$ of the children, where HIV status was documented, were HIV negative. Following the addition of a booster dose of Hib vaccine in 2009, as a pentavalent vaccine (DTaP-Hib-IPV) the incidence of invasive Hib declined [92]. In 2018, GERMS identified 327 cases of invasive H. influenzae infection, of which 201 were available for typing. Seventeen percent $(34 / 201)$ were Hib, of which eight cases presented with meningitis [95].

\subsection{Resurgence of Hib in the Gambia}

The Gambia introduced Hib vaccine in 1997. Before the Gambia introduced routine Hib vaccination, Hib meningitis incidence was 297/100,000 in infants <one year of age and $60 / 100,000$ in children aged <five years [27]. The Gambia used a three-dose primary series of PRP-TT Hib vaccine, administered at two, three, and four months without a booster dose. For 14 years invasive Hib disease was well controlled in this country with consistently high coverage, low carriage rates and high levels of protective antibodies [96]. On-going surveillance in eastern Gambia identified an increase in Hib infections between 2011 and 2013, with 17 cases of invasive Hib infection, including 14 cases of Hib meningitis [97]. Although the reason for this re-emergence is not entirely clear, it does emphasize the importance of on-going surveillance.

\subsection{Is a Booster Dose of Hib Vaccine Needed?}

Although these instances where invasive Hib infections have emerged were in countries using a three dose primary series of Hib vaccine without a booster dose, Kenya and most LMICs use this schedule with no evidence of a resurgence of invasive Hib cases [98]. A three dose primary series of Hib vaccine without a booster dose is recommended by WHO [66]. A meta-analysis of 20 RCTs, conducted in 15 countries comparing different Hib vaccination schedules $(3+0,3+1$, and $2+1)$ and different intervals between the primary, and the primary and booster doses, concluded that there was no difference between the schedules in terms of preventing invasive Hib disease, clinical effectiveness or immunologic response. All of the schedules protected against Hib infection and local epidemiology should determine the schedule, with three doses in the first six months of life being more appropriate where the greatest burden of Hib infection is in the first year of life, as in sub-Saharan Africa. Where the burden of infection occurs at a later age, the third dose could be given in the second year of life. In countries like the UK, where Hib infections resurged with a $3+0$ schedule, a booster in the second year of life may be required [99]. Children who are HIV infected may require a booster dose of vaccine [100].

\section{Current Burden of $\boldsymbol{H}$. influenzae Meningitis}

When Hib vaccine was first introduced there were concerns that Hib meningitis might be replaced by infections caused by other serotypes of $H$. influenzae. This has generally not happened, except in the Indigenous communities of North America, where H. influenzae serotype a (Hia) has emerged as a significant pathogen $[23,101]$. There has also been a slight increase in infections, including meningitis, caused by Hie and Hif in Europe [102,103]. Invasive infections caused by non-typeable strains of H. influenzae (NTHi) have increased significantly in many regions of the world $[103,104]$. 


\section{Meningitis Due to Non-b Serotypes of $H$. influenzae}

\subsection{Meningitis Due to Serotype a (Hia)}

Before the introduction of Hib vaccine, invasive $H$. influenzae serotype a (Hia) disease was very uncommon, although Hia was responsible for $12 \%$ of cases of bacterial meningitis in young children in Papua New Guinea before the introduction of Hib immunization $[105,106]$. Over the last two decades Hia has emerged as a significant pathogen, particularly in Indigenous populations in North America [23]. High incidences of Hia infection have been reported in Alaska Native, American Indian, and Canadian Inuit children [29,107-110]. In 2011, a population-based study in 12 Canadian pediatric tertiary care centers reported an Hia incidence of 418.8/100,000 in Inuit children aged < five years in the Keewatin region [111]. Hia is the second most virulent capsular serotype of $H$. influenzae [112] and can cause meningitis, pneumonia, septic arthritis, and bacteremia [23]. Most Hia infections occur in children aged six months to two years [23]. Between 1998 and 2003 38/76 (50\%) of cases of Hia infection identified in Navajo and White Mountain Apache children presented with meningitis [107]. Hia meningitis was the commonest presentation in Indigenous children in the North American Arctic and Northern Canada [108,110]. Hia has also emerged as a significant pathogen in Utah and North and South Dakota [113-117]. In a study in Utah from 1998 to 2008, 28\% of all invasive disease in children aged < five years was due to Hia, and 18\% due to Hib. Fifty percent of the Hia cases presented as meningitis [115]. Hia infections in these states were not exclusively in American Indian children. Hia infections have also been reported from Brazil [118-120]. The case fatality rate of Hia meningitis was 14\% in Brazil [120], 16\% in Northern Canada [110], and 6\% in the North American Arctic [112]. Hia has also been reported in Italy [121] and England [122] but there were no cases of meningitis in these reports of infections, which predominantly occurred in adults. Hia meningitis in a 10 month old infant and a 3 year old child was reported from Saudi Arabia [123]. The emergence of Hia as a significant cause of invasive infections in certain populations has prompted the development of an Hia conjugate vaccine [124].

\subsection{Meningitis Due to Serotypes e and $f$ (Hie and Hif)}

There has also been increasing recognition of cases of meningitis caused by Hie and Hif [102]. Between 2001 and 2010 the year on year incidence of Hie and Hif infections in England and Wales increased by $7.4 \%$ and $11.0 \%$ respectively [100]. In 2009-2010, the incidences of Hie and Hif infections were $0.03 / 100,000$ persons and 0.09/100,000 persons, respectively, with the highest rates being seen in infants and older adults [102]. Nine of 10 cases occurring in infants aged <one year presented with meningitis (three Hie, six Hif). All of the infants with Hif meningitis survived, but one child with Hie meningitis died, one had severe bilateral sensorineural deafness and one developed seizures [102]. Meningitis was a less common presentation in older children and adults, with three cases of Hie meningitis (one child aged one to four years, one child aged five to 14 years, one adult aged 15-64 years) and four cases of Hif meningitis (one in a child aged one to four years, three in adults aged 15-64 years). The case fatality rates of Hie and Hif meningitis were $14.3 \%$ and $0 \%$, respectively. In this study Hie meningitis was associated with more complications and a higher case fatality rate.

Whittaker et al. [125] analyzed reports of invasive H. influenzae infection reported by 12 European countries to the European Centre for Disease Prevention and Control (ECDC) between 2007 and 2014. Five hundred and ninety-six cases of meningitis were reported, representing $9 \%$ of all infections. Sixty percent and $40 \%$ of infants aged <one year with Hie or Hif infection were reported to have meningitis [125]. National surveillance in Germany between 2001 and 2016 identified 351 cases of capsulated H. influenzae invasive infection: 241 cases of Hif, 45 cases of Hie, seven cases of Hia, and 58 cases of Hib(126). Forty cases of Hif infection were in children aged $<$ four years with $40 \%$ of these cases presenting as meningitis. There were 185 cases of Hif infection in adults aged $\geq 40$ years 
with meningitis accounting for 15\% [126]. Hif meningitis has also been reported in the United States [127-129] and in Sweden [130].

\subsection{Meningitis Due to Non-Typeable H.influenzae (NTHi)}

Since the introduction of Hib vaccine, NTHi infections have emerged as the most common cause of invasive $H$. infuenzae infection in many parts of the world, where surveillance has been undertaken $[104,113,125-128,130-139]$. The highest burden of NTHi infections is seen in neonates, children aged <one year, pregnant/post-partum women, and in older adults ( $\geq 65$ years) [104]. The clinical presentation varies by age, with meningitis more commonly seen in older infants and children and pneumonia more common in older adults [104].

Over a five year period (2009-2013), there were 115 cases of neonatal invasive NTHi infection in England and Wales (incidence 4.1/100,000; 95\% CI 3.4-5.0) [24]. The incidence was significantly higher in premature babies (28.4/100,000; $95 \%$ CI 22.8-35.0) compared to those born at term $(0.9 / 100,000 ; 95 \%$ CI $0.6-1.4)$ and increased exponentially with increasing prematurity. For infants born at $<28$ weeks' gestation the incidence was 342/100,000 (95\% CI, 234-483). Most cases $(110 / 115,96 \%)$ presented within $48 \mathrm{~h}$ of birth. Although most of the infants developed a bacteremia, $11(10 \%)$ presented with meningitis. One infant with meningitis died and five (50\%) developed long-term sequelae [24].

Active surveillance for invasive $H$. influenzae disease in the US ABC surveillance sites from 2009 to 2015, reported that invasive NTHi infections had the highest incidence $(1.22 / 100,000)$ [113]. Among 317 cases of invasive H. influenzae infection in children aged $<$ one year, 25.1\% presented with meningitis. One hundred and ninety six of $294(66.7 \%)$ invasive infections (where the serotype was known) in this age group were due to NTHi. Although the serotyping of the meningitis cases was not reported it is probable that they included cases of NTHi meningitis.

Between 2001 and 2008, there were 396 cases of invasive NTHi infection documented by the Netherlands Reference Laboratory for Bacterial Meningitis [134]. Overall, the most common presenting clinical syndrome was invasive pneumonia $(190 / 396,48 \%)$ followed by bacteremia $(75 / 396,19 \%)$. Fifty-seven $(14 \%)$ of the cases presented with meningitis. Among children aged seven weeks to $<$ five years 28/60 (47\%) of cases were meningitis. Nationwide active surveillance in Germany between 1998 and 2005 identified 70 cases of invasive NTHi infection. The median age of presentation was 26 months (0-73 months) and $34 \%$ presented with meningitis [135]. Thirty eight percent of children with NTHi meningitis had predisposing conditions, including prematurity, immunodeficiency, and Down's syndrome [135]. In a study from England [131] 26\% of children who survived NTHi meningitis suffered long-term sequelae, including deafness, seizures, and hydrocephalus [131]. The case fatality rate of NTHi meningitis is similar to that of Hib meningitis [131].

\section{Conclusions}

Hib conjugate vaccine has been a remarkable success story, reducing the incidence of Hib meningitis to a very low level in countries with a well-established Hib immunization program and sustained high vaccine coverage [140]. There has been considerable progress in achieving the elimination of $H$. influenzae meningitis, but more still needs to be done. Cases of Hib meningitis do still occur, in unimmunized or partially vaccinated children, and as rare instances of true Hib vaccine failures. In 2015, Wahl et al. [73] estimated that there were still 12,900 cases (UR 6400 to 21,500) of Hib meningitis globally. Since then, Hib vaccine has been introduced into the NIP of almost all countries, including India and Thailand, except for China and the Russian Federation (where Hib vaccine is recommended for certain risk groups). Every child in the world should be offered Hib vaccine and vaccine coverage needs to be maintained at a high level in all countries. Hia has emerged as a significant cause of meningitis in Indigenous populations of North America, potentially requiring the use of Hia conjugate vaccine in these high-risk populations. Hie, Hif, and NTHi have also been associated with cases of meningitis. The changing epidemiology of $H$. 
influenzae meningitis emphasizes the importance of on-going surveillance. Epidemiologic and microbiologic surveillance should be comprehensive, covering all ages and all types of $H$. influenzae. Accurate typing of strains, using molecular methods combined with clinical ascertainment of clinical presentation, underlying risk factors and outcome should be undertaken to fully document these changes. Considerable progress in achieving the elimination of $H$. influenzae meningitis has been made, but more still needs to be done.

Funding: This research received no external funding.

Institutional Review Board Statement: Not applicable.

Informed Consent Statement: Not applicable.

Data Availability Statement: Data available in a publicly available repository (PubMed).

Conflicts of Interest: MPES has received personal fees from GSK, Pfizer, AstraZeneca, and Sanofi Pasteur as a speaker at international meetings and as a member of advisory boards (unrelated to the submitted work).

\section{References}

1. Pittman, M. Variation and type specificity in the bacterial species Haemophilus influenzae. J. Exp. Med. 1931, 53, 471-492. [CrossRef] [PubMed]

2. Kilian, M.; Frederiksen, W. Ecology of Haemophilus, Pasteurella and Actinobacillus. In Haemophilus, Pasteurella and Actinobacillus; Kilian, M., Frederiksen, W., Biberstein, E.L., Eds.; Academic Press: London, UK, 1981; pp. 11-38.

3. Ingham, H.R.; Turk, D.C. Haemophili from eyes. J. Clin. Pathol. 1969, 22, 258-262. [CrossRef]

4. Moxon, E.R. Haemophilus influenzae. In Mandell, Douglas abnd Bennett's Principles and Practice of Infectious Disease, 4th ed.; Mandell, G.L., Bennett, J., Dolin, R., Eds.; Churchill Livingstone: New York, NY, USA, 1995; Volume 2, pp. $2039-2050$.

5. Hammerschlag, M.R.; Alpert, S.; Rosner, I.; Thurston, P.; Semine, D.; McComb, D.; McCormack, W.M. Microbiology of the vagina in children: Normal and potentially pathogenic organisms. Pediatrics 1978, 62, 57-62. [PubMed]

6. Cox, R.A.; Slack, M.P. Clinical and microbiological features of Haemophilus influenzae vulvovaginitis in young girls. J. Clin. Pathol. 2002, 55, 961-964. [CrossRef] [PubMed]

7. Moxon, E.R. The carrier state: Haemophilus influenzae. J. Antimicrob. Chemother. 1986, 18, 17-24. [CrossRef] [PubMed]

8. Kilian, M.; Frederiksen, W.; Biberstein, E.L. Haemophilus, Pasteurella and Actinobacillus; Academic Press Inc.: London, UK, 1981; 294 .

9. Wenger, J.D.; Hightower, A.W.; Facklam, R.R.; Gaventa, S.; Broome, C.V. Bacterial meningitis in the United States, 1986: Report of a multistate surveillance study. The Bacterial Meningitis Study Group. J. Infect. Dis. 1990, 162, 1316-1323. [CrossRef]

10. Broome, C.V. Epidemiology of Haemophilus influenzae type b infections in the United States. Pediatr. Infect. Dis. J. 1987, 6, 779-782. [CrossRef]

11. Salwén, K.M.; Vikerfors, T.; Olcén, P. Increased incidence of childhood bacterial meningitis. A 25-year study in a defined population in Sweden. Scand. J. Infect. Dis. 1987, 19, 1-11. [CrossRef]

12. Snaebjarnardóttir, K.; Erlendsdóttir, H.; Reynisson, I.K.; Kristinsson, K.; Halldórsdóttir, S.; Hardardóttir, H.; Gudnason, T.; Gottfredsson, M.; Haraldsson, Á. Bacterial meningitis in children in Iceland, 1975-2010: A nationwide epidemiological study. Scand. J. Infect. Dis. 2013, 45, 819-824. [CrossRef]

13. Spanjaard, L.; Bol, P.; Ekker, W.; Zanen, H.C. The incidence of bacterial meningitis in the Netherlands-a comparison of three registration systems, 1977-1982. J. Infect. 1985, 11, 259-268. [CrossRef]

14. Davison, K.L.; Ramsay, M.E. The epidemiology of acute meningitis in children in England and Wales. Arch. Dis. Child. 2003, 88, 662-664. [CrossRef]

15. Måkelå, P.H.; Takala, A.K.; Peltola, H.; Eskola, J. Epidemiology of Invasive Haemophilus influenzae Type b Disease. J. Infect. Dis. 1992, 165, S2-S6. [CrossRef]

16. Wilfert, C.M. Epidemiology of Haemophilus influenzae type b infections. Pediatrics 1990, 85, 631-635.

17. World Health Organization. Haemophilus influenzae Type b (Hib) Meningitis in the Pre-Vaccine Era: A Global Review of Incidence, Age Distributions, and Case-Fatality Rates; World Health Organization: Geneva, Switzerland, 2002; Available online: https: / / apps.who.int/iris/handle/10665/67572 (accessed on 6 April 2021).

18. Fothergill, L.D.; Wright, J. Influenzal Meningitis. J. Immunol. 1933, 24, 273.

19. Peltola, H.; Käyhty, H.; Sivonen, A.; Mäkelä, H. Haemophilus influenzae type b capsular polysaccharide vaccine in children: A double-blind field study of 100,000 vaccinees 3 months to 5 years of age in Finland. Pediatrics 1977, 60, 730-737.

20. Käyhty, H.; Peltola, H.; Karanko, V.; Mäkelä, P.H. The protective level of serum antibodies to the capsular polysaccharide of Haemophilus influenzae type b. J. Infect. Dis. 1983, 147, 1100. [CrossRef]

21. Anderson, P. The protective level of serum antibodies to the capsular polysaccharide of Haemophilus influenzae type b. J. Infect. Dis. 1984, 149, 1034-1035. [CrossRef] [PubMed] 
22. Collins, S.; Ramsay, M.; Campbell, H.; Slack, M.P.; Ladhani, S.N. Invasive Haemophilus influenzae type b disease in England and Wales: Who is at risk after 2 decades of routine childhood vaccination? Clin. Infect. Dis. Off. Publ. Infect. Dis. Soc. Am. 2013, 57, 1715-1721. [CrossRef] [PubMed]

23. Ulanova, M.; Tsang, R.S.W. Haemophilus influenzae serotype a as a cause of serious invasive infections. Lancet Infect. Dis. 2014, 14, 70-82. [CrossRef]

24. Collins, S.; Litt, D.J.; Flynn, S.; Ramsay, M.E.; Slack, M.P.; Ladhani, S.N. Neonatal invasive Haemophilus influenzae disease in England and Wales: Epidemiology, clinical characteristics, and outcome. Clin. Infect. Dis. Off. Publ. Infect. Dis. Soc. Am. 2015, 60, 1786-1792. [CrossRef] [PubMed]

25. World Health Organization. Defeating Meningitis by 2030. Available online: https://www.who.int/initiatives/defeatingmeningitis-by-2030 (accessed on 6 April 2021).

26. Peltola, H. Worldwide Haemophilus influenzae type b disease at the beginning of the 21st century: Global analysis of the disease burden 25 years after the use of the polysaccharide vaccine and a decade after the advent of conjugates. Clin. Microbiol. Rev. 2000, 13, 302-317. [CrossRef]

27. Bijlmer, H.A.; van Alphen, L.; Greenwood, B.M.; Brown, J.; Schneider, G.; Hughes, A.; Menon, A.; Zanen, H.C.; Valkenburg, H.A. The epidemiology of Haemophilus influenzae meningitis in children under five years of age in The Gambia, West Africa. J. Infect. Dis. 1990, 161, 1210-1215. [CrossRef]

28. Ward, J.I.; Margolis, H.S.; Lum, M.K.; Fraser, D.W.; Bender, T.R.; Anderson, P. Haemophilus influenzae disease in Alaskan Eskimos: Characteristics of a population with an unusual incidence of invasive disease. Lancet 1981, 1, 1281-1285. [CrossRef]

29. Losonsky, G.A.; Santosham, M.; Sehgal, V.M.; Zwahlen, A.; Moxon, E.R. Haemophilus influenzae disease in the White Mountain Apaches: Molecular epidemiology of a high risk population. Pediatr. Infect. Dis. 1984, 3, 539-547. [CrossRef] [PubMed]

30. Coulehan, J.L.; Michaels, R.H.; Hallowell, C.; Schults, R.; Welty, T.K.; Kuo, J.S. Epidemiology of Haemophilus influenzae type B disease among Navajo Indians. Public Health Rep. 1984, 99, 404-409.

31. Hanna, J.N.; Wild, B.E. Bacterial meningitis in children under five years of age in Western Australia. Med. J. Aust. 1991, 155, 160-164. [CrossRef] [PubMed]

32. Hammond, G.W.; Rutherford, B.E.; Malazdrewicz, R.; MacFarlane, N.; Pillay, N.; Tate, R.B.; Nicolle, L.E.; Postl, B.D.; Stiver, H.G Haemophilus influenzae meningitis in Manitoba and the Keewatin District, NWT: Potential for mass vaccination. Can. Med. Assoc. J. 1988, 139, 743-747.

33. Bijlmer, H.A. World-wide epidemiology of Haemophilus influenzae meningitis; industrialized versus non-industrialized countries. Vaccine 1991, 9, S5-S9. [CrossRef]

34. Gilbert, G.L. Epidemiology of Haemophilus influenzae type b disease in Australia and New Zealand. Vaccine 1991, 9, S10-S13, discussion S25. [CrossRef]

35. Ward, J.I.; Lum, M.K.; Hall, D.B.; Silimperi, D.R.; Bender, T.R. Invasive Haemophilus influenzae type b disease in Alaska: Background epidemiology for a vaccine efficacy trial. J. Infect. Dis. 1986, 153, 17-26. [CrossRef] [PubMed]

36. Takala, A.K.; Eskola, J.; Peltola, H.; Måkelå, P.H. Epidemiology of invasive Haemophilus influenzae type b disease among children in Finland before vaccination with Haemophilus influenzae type b conjugate vaccine. Pediatr. Infect. Dis. J. 1989, 8, $297-302$. [CrossRef] [PubMed]

37. Anderson, E.C.; Begg, N.T.; Crawshaw, S.C.; Hargreaves, R.M.; Howard, A.J.; Slack, M.P. Epidemiology of invasive Haemophilus influenzae infections in England and Wales in the pre-vaccination era (1990-2). Epidemiol. Infect. 1995, 115, 89-100. [CrossRef] [PubMed]

38. Clements, D.A.; Booy, R.; Dagan, R.; Gilbert, G.L.; Moxon, E.R.; Slack, M.P.; Takala, A.; Zimmermann, H.P.; Zuber, P.L.; Eskola, J. Comparison of the epidemiology and cost of Haemophilus influenzae type b disease in five western countries. Pediatr. Infect. Dis. J. 1993, 12, 362-367. [CrossRef]

39. Gervaix, A.; Suter, S. Epidemiology of invasive Haemophilus influenzae type b infections in Geneva, Switzerland, 1976 to 1989. Pediatr. Infect. Dis. J. 1991, 10, 370-374. [CrossRef] [PubMed]

40. Trollfors, B.; Claesson, B.A.; Strangert, K.; Taranger, J. Haemophilus influenzae meningitis in Sweden 1981-1983. Arch. Dis. Child. 1987, 62, 1220-1223. [CrossRef] [PubMed]

41. Dagan, R. Epidemiology of invasive Haemophilus influenzae type b (Hib) disease in Israel. Vaccine 1993, 11 (Suppl. 1), S43-S45. [CrossRef]

42. Gilbert, G.L.; Clements, D.A.; Broughton, S.J. Haemophilus influenzae type b infections in Victoria, Australia, 1985 to 1987 Pediatr. Infect. Dis. J. 1990, 9, 252-257. [CrossRef]

43. Hansman, D.; Hanna, J.; Morey, F. High prevalence of invasive Haemophilus influenzae disease in central Australia, 1986. Lancet 1986, 2, 927. [CrossRef]

44. Peltola, H. Haemophilus influenzae type b disease and vaccination in Latin America and the Caribbean. Pediatr. Infect. Dis. J. 1997, 16, 780-787. [CrossRef]

45. Peltola, H. Spectrum and burden of severe Haemophilus influenzae type b diseases in Asia. Bull. World Health Organ. 1999, $77,878-887$.

46. Scott, S.; Altanseseg, D.; Sodbayer, D.; Nymadawa, P.; Bulgan, D.; Mendsaikhan, J.; Watt, J.P.; Slack, M.P.; Carvalho, M.G.; Hajjeh, R.; et al. Impact of Haemophilus influenzae Type b conjugate vaccine in Mongolia: Prospective population-based surveillance, 2002-2010. J. Pediatr. 2013, 163, S8-S11. [CrossRef] [PubMed] 
47. Grimwood, K.; Anderson, V.A.; Bond, L.; Catroppa, C.; Hore, R.L.; Keir, E.H.; Nolan, T.; Roberton, D.M. Adverse outcomes of bacterial meningitis in school-age survivors. Pediatrics 1995, 95, 646-656.

48. Baraff, L.J.; Lee, S.I.; Schriger, D.L. Outcomes of bacterial meningitis in children: A meta-analysis. Pediatr. Infect. Dis. J. 1993, 12, 389-394. [CrossRef] [PubMed]

49. Letson, G.W.; Gellin, B.G.; Bulkow, L.R.; Parks, D.J.; Ward, J.I. Severity and frequency of sequelae of bacterial meningitis in Alaska Native infants. Correlation with a scoring system for severity of sequelae. Am. J. Dis. Child. 1992, 146, 560-566. [CrossRef] [PubMed]

50. D'Angio, C.T.; Froehlke, R.G.; Plank, G.A.; Meehan, D.J.; Aguilar, C.M.; Lande, M.B.; Hugar, L. Long-term Outcome of Haemophilus influenzae Meningitis in Navajo Indian Children. Arch. Pediatr. Adolesc. Med. 1995, 149, 1001-1008. [CrossRef]

51. Goetghebuer, T.; West, T.E.; Wermenbol, V.; Cadbury, A.L.; Milligan, P.; Lloyd-Evans, N.; Adegbola, R.A.; Mulholland, E.K.; Greenwood, B.M.; Weber, M.W. Outcome of meningitis caused by Streptococcus pneumoniae and Haemophilus influenzae type b in children in The Gambia. Trop. Med. Int. Health 2000, 5, 207-213. [CrossRef]

52. Eskola, J.; Peltola, H.; Takala, A.K.; Käyhty, H.; Hakulinen, M.; Karanko, V.; Kela, E.; Rekola, P.; Ronnberg, P.R.; Samuelson, J.S.; et al. Efficacy of Haemophilus influenzae type b polysaccharide-diphtheria toxoid conjugate vaccine in infancy. N. Engl. J. Med. 1987, 317, 717-722. [CrossRef]

53. Käyhty, H.; Karanko, V.; Peltola, H.; Mäkelä, P.H. Serum antibodies after vaccination with Haemophilus influenzae type b capsular polysaccharide and responses to reimmunization: No evidence of immunologic tolerance or memory. Pediatrics 1984, 74, 857-865.

54. O'Brien, K.L.; Steinhoff, M.C.; Edwards, K.; Keyserling, H.; Thoms, M.L.; Madore, D. Immunologic priming of young children by pneumococcal glycoprotein conjugate, but not polysaccharide, vaccines. Pediatr. Infect. Dis. J. 1996, 15, 425-430. [CrossRef]

55. Ladhani, S.N. Two decades of experience with the Haemophilus influenzae serotype b conjugate vaccine in the United Kingdom. Clin. Ther. 2012, 34, 385-399. [CrossRef]

56. Anderson, P.; Pichichero, M.E.; Insel, R.A. Immunization of 2-month-old infants with protein-coupled oligosaccharides derived from the capsule of Haemophilus influenzae type b. J. Pediatr. 1985, 107, 346-351. [CrossRef]

57. Barbour, M.L.; Booy, R.; Crook, D.W.; Griffiths, H.; Chapel, H.M.; Moxon, E.R.; Mayon-White, D. Haemophilus influenzae type b carriage and immunity four years after receiving the Haemophilus influenzae oligosaccharide-CRM197 (HbOC) conjugate vaccine. Pediatr. Infect. Dis. J. 1993, 12, 478-484. [CrossRef]

58. Kelly, D.F.; Moxon, E.R.; Pollard, A.J. Haemophilus influenzae type b conjugate vaccines. Immunology 2004, 113, 163-174. [CrossRef] [PubMed]

59. Ward, J.; Brenneman, G.; Letson, G.W.; Heyward, W.L. Limited efficacy of a Haemophilus influenzae type b conjugate vaccine in Alaska Native infants. The Alaska H. influenzae Vaccine Study Group. N. Engl. J. Med. 1990, 323, 1393-1401. [CrossRef] [PubMed]

60. Bulkow, L.R.; Wainwright, R.B.; Letson, G.W.; Chang, S.J.; Ward, J.I. Comparative immunogenicity of four Haemophilus influenzae type b conjugate vaccines in Alaska Native infants. Pediatr. Infect. Dis. J. 1993, 12, 484-492. [CrossRef] [PubMed]

61. Decker, M.D.; Edwards, K.M.; Bradley, R.; Palmer, P. Comparative trial in infants of four conjugate Haemophilus influenzae type b vaccines. J. Pediatr. 1992, 120, 184-189. [CrossRef]

62. Centers for Disease Control. Haemophilus b Conjugate Vaccines for Prevention of Haemophilus influenzae Type b Disease among Infants and Children Two Months of Age and Older: Recommendations of the Immunization Practices Advisory Committee (ACIP). Available online: https://www.cdc.gov/mmwr/preview/mmwrhtml/00041736.htm (accessed on 6 April 2021).

63. Gessner, B.D.; Sutanto, A.; Linehan, M.; Djelantik, I.G.; Fletcher, T.; Gerudug, I.K.; Mercer, D.; Moniaga, V.; Moulton, L.H.; Mulholland, K.; et al. Incidences of vaccine-preventable Haemophilus influenzae type b pneumonia and meningitis in Indonesian children: Hamlet-randomised vaccine-probe trial. Lancet 2005, 365, 43-52. [CrossRef]

64. Feikin, D.R.; Nelson, C.B.; Watt, J.P.; Mohsni, E.; Wenger, J.D.; Levine, O.S. Rapid assessment tool for Haemophilus influenzae type b disease in developing countries. Emerg. Infect. Dis. 2004, 10, 1270-1276. [CrossRef]

65. Hajjeh, R.A.; Privor-Dumm, L.; Edmond, K.; O’Loughlin, R.; Shetty, S.; Griffiths, U.K.; Bear, A.P.; Cohen, A.L.; Chandran, A.; Schuchat, A.; et al. Supporting new vaccine introduction decisions: Lessons learned from the Hib Initiative experience. Vaccine 2010, 28, 7123-7129. [CrossRef]

66. World Health Organization. WHO Position Paper on Haemophilus influenzae type b conjugate vaccines. Wkly. Epidemiol. Rec. 2006, $81,445-452$.

67. Ojo, L.R.; O’Loughlin, R.E.; Cohen, A.L.; Loo, J.D.; Edmond, K.M.; Shetty, S.S.; Bear, A.P.; Privor-Dumm, L.; Griffiths, U.K.; Hajjeh, R. Global use of Haemophilus influenzae type b conjugate vaccine. Vaccine 2010, 28, 7117-7122. [CrossRef]

68. International Vaccine Access Center. VIEW-Hub Report:Global Vaccine Introduction and Implementation. Available online: https://www.jhsph.edu/ivac/wp-content/uploads/2021/02/VIEW-hubReport_Dec2020.pdf (accessed on 6 April 2021).

69. Swingler, G.; Fransman, D.; Hussey, G. Conjugate vaccines for preventing Haemophilus influenzae type b infections. Cochrane Database Syst. Rev. 2007, Cd001729. [CrossRef]

70. Watt, J.P.; Levine, O.S.; Santosham, M. Global reduction of Hib disease: What are the next steps? Proceedings of the meeting Scottsdale, Arizona, 22-25 September 2002. J. Pediatr. 2003, 143, S163-S187. [CrossRef]

71. McIntyre, P.B.; O’Brien, K.L.; Greenwood, B.; van de Beek, D. Effect of vaccines on bacterial meningitis worldwide. Lancet 2012, 380, 1703-1711. [CrossRef] 
72. Watt, J.P.; Wolfson, L.J.; O’Brien, K.L.; Henkle, E.; Deloria-Knoll, M.; McCall, N.; Lee, E.; Levine, O.S.; Hajjeh, R.; Mulholland, K.; et al. Burden of disease caused by Haemophilus influenzae type b in children younger than 5 years: Global estimates. Lancet 2009, 374, 903-911. [CrossRef]

73. Wahl, B.; O’Brien, K.L.; Greenbaum, A.; Majumder, A.; Liu, L.; Chu, Y.; Luksic, I.; Nair, H.; McAllister, D.A.; Campbell, H.; et al. Burden of Streptococcus pneumoniae and Haemophilus influenzae type b disease in children in the era of conjugate vaccines: Global, regional, and national estimates for 2000-15. Lancet. Glob. Health 2018, 6, e744-e757. [CrossRef]

74. Davis, S.; Feikin, D.; Johnson, H.L. The effect of Haemophilus influenzae type $b$ and pneumococcal conjugate vaccines on childhood meningitis mortality: A systematic review. BMC Public Health 2013, 13 (Suppl. 3), S21. [CrossRef]

75. Morris, S.K.; Moss, W.J.; Halsey, N. Haemophilus influenzae type b conjugate vaccine use and effectiveness. Lancet Infect. Dis. 2008, 8, 435-443. [CrossRef]

76. Schuchat, A.; Hilger, T.; Zell, E.; Farley, M.M.; Reingold, A.; Harrison, L.; Lefkowitz, L.; Danila, R.; Stefonek, K.; Barrett, N.; et al. Active bacterial core surveillance of the emerging infections program network. Emerg. Infect. Dis. 2001, 7, 92-99. [CrossRef] [PubMed]

77. Thigpen, M.C.; Whitney, C.G.; Messonnier, N.E.; Zell, E.R.; Lynfield, R.; Hadler, J.L.; Harrison, L.H.; Farley, M.M.; Reingold, A.; Bennett, N.M.; et al. Bacterial meningitis in the United States, 1998-2007. N. Engl. J. Med. 2011, 364, 2016-2025. [CrossRef] [PubMed]

78. Centers for Disease Control and Prevention. Nationally Notifiable Infectious Diseases and Conditions, United States: Annual Tables. Available online: https://wonder.cdc.gov/nndss/static/2018/annual/2018-table1.html (accessed on 6 April 2021).

79. Polkowska, A.; Toropainen, M.; Ollgren, J.; Lyytikäinen, O.; Nuorti, J.P. Bacterial meningitis in Finland, 1995-2014: A populationbased observational study. BMJ Open 2017, 7, e015080. [CrossRef]

80. Ali, M.; Chang, B.A.; Johnson, K.W.; Morris, S.K. Incidence and aetiology of bacterial meningitis among children aged 1-59 months in South Asia: Systematic review and meta-analysis. Vaccine 2018, 36, 5846-5857. [CrossRef]

81. Ceyhan, M.; Ozsurekci, Y.; Tanır Basaranoglu, S.; Gurler, N.; Sali, E.; Keser Emiroglu, M.; Oz, F.N.; Belet, N.; Duman, M.; Ulusoy, E.; et al. Multicenter Hospital-Based Prospective Surveillance Study of Bacterial Agents Causing Meningitis and Seroprevalence of Different Serogroups of Neisseria meningitidis, Haemophilus influenzae type b, and Streptococcus pneumoniae during 2015 to 2018 in Turkey. mSphere 2020, 5. [CrossRef] [PubMed]

82. Suga, S.; Ishiwada, N.; Sasaki, Y.; Akeda, H.; Nishi, J.; Okada, K.; Fujieda, M.; Oda, M.; Asada, K.; Nakano, T.; et al. A nationwide population-based surveillance of invasive Haemophilus influenzae diseases in children after the introduction of the Haemophilus influenzae type b vaccine in Japan. Vaccine 2018, 36, 5678-5684. [CrossRef] [PubMed]

83. Ladhani, S.N.; Ramsay, M.; Slack, M.P. The impact of Haemophilus influenzae serotype b resurgence on the epidemiology of childhood invasive Haemophilus influenzae disease in England and Wales. Pediatr. Infect. Dis. J. 2011, 30, 893-895. [CrossRef] [PubMed]

84. McVernon, J.; Andrews, N.; Slack, M.P.; Ramsay, M.E. Risk of vaccine failure after Haemophilus influenzae type b (Hib) combination vaccines with acellular pertussis. Lancet 2003, 361, 1521-1523. [CrossRef]

85. McVernon, J.; Johnson, P.D.; Pollard, A.J.; Slack, M.P.; Moxon, E.R. Immunologic memory in Haemophilus influenzae type b conjugate vaccine failure. Arch. Dis. Child. 2003, 88, 379-383. [CrossRef] [PubMed]

86. Ramsay, M.E.; McVernon, J.; Andrews, N.J.; Heath, P.T.; Slack, M.P. Estimating Haemophilus influenzae type b vaccine effectiveness in England and Wales by use of the screening method. J. Infect. Dis. 2003, 188, 481-485. [CrossRef]

87. McVernon, J.; Howard, A.J.; Slack, M.P.; Ramsay, M.E. Long-term impact of vaccination on Haemophilus influenzae type b (Hib) carriage in the United Kingdom. Epidemiol. Infect. 2004, 132, 765-767. [CrossRef]

88. Johnson, N.G.; Ruggeberg, J.U.; Balfour, G.F.; Lee, Y.C.; Liddy, H.; Irving, D.; Sheldon, J.; Slack, M.P.; Pollard, A.J.; Heath, P.T Haemophilus influenzae type b reemergence after combination immunization. Emerg. Infect. Dis. 2006, 12, 937-941. [CrossRef]

89. Trotter, C.L.; McVernon, J.; Andrews, N.J.; Burrage, M.; Ramsay, M.E. Antibody to Haemophilus influenzae type b after routine and catch-up vaccination. Lancet 2003, 361, 1523-1524. [CrossRef]

90. Ladhani, S.; Slack, M.P.; Heys, M.; White, J.; Ramsay, M.E. Fall in Haemophilus influenzae serotype b (Hib) disease following implementation of a booster campaign. Arch. Dis. Child. 2008, 93, 665-669. [CrossRef] [PubMed]

91. Department of Health. Immunisation against Infectious Diseases Chapter 16: Haemophilus influenzae Type b (Hib). Available online: https:/ / www.gov.uk/government/publications/haemophilus-influenzae-type-hib-the-green-book-chapter-16 (accessed on 6 April 2021).

92. Litt, D.; Fry, N.K.; Ladhani, S.N. Epidemiology of invasive Haemophilus influenzae disease in England: National surveillance, 2017-2018 PO-019-(EMGM2019-13268). In Proceedings of the 15th EMGM Congress, Lisbon, Portugal, 27-30 May 2019; Available online: https:/ / www.gov.uk/government/publications/haemophilus-influenzae-type-hib-the-green-book-chapter-16 (accessed on 6 April 2021).

93. Von Gottberg, A.; de Gouveia, L.; Madhi, S.A.; du Plessis, M.; Quan, V.; Soma, K.; Huebner, R.; Flannery, B.; Schuchat, A.; Klugman, K. Impact of conjugate Haemophilus influenzae type b (Hib) vaccine introduction in South Africa. Bull. World Health Organ. 2006, 84, 811-818. [CrossRef]

94. Von Gottberg, A.; Cohen, C.; Whitelaw, A.; Chhagan, M.; Flannery, B.; Cohen, A.L.; de Gouveia, L.; Plessis, M.; Madhi, S.A.; Klugman, K.P. Invasive disease due to Haemophilus influenzae serotype b ten years after routine vaccination, South Africa, 2003-2009. Vaccine 2012, 30, 565-571. [CrossRef] [PubMed] 
95. National Institute for Communicable Diseases. GERMS South Africa Annual Surveillance Review 2018. Available online: https://www.nicd.ac.za/wp-content/uploads/2019/11/GERMS-SA-AR-2018-Final.pdf (accessed on 6 April 2021).

96. Howie, S.R.; Oluwalana, C.; Secka, O.; Scott, S.; Ideh, R.C.; Ebruke, B.E.; Balloch, A.; Sambou, S.; Erskine, J.; Lowe, Y.; et al. The effectiveness of conjugate Haemophilus influenzae type b vaccine in The Gambia 14 years after introduction. Clin. Infect. Dis. Off. Publ. Infect. Dis. Soc. Am. 2013, 57, 1527-1534. [CrossRef] [PubMed]

97. Mackenzie, G.A.; Ikumapayi, U.N.; Scott, S.; Idoko, O.; Odutola, A.; Ndiaye, M.; Sahito, S.M.; Osuorah, C.D.; Manjang, A.; Jarju, S.; et al. Increased disease due to Haemophilus influenzae type b: Population-based surveillance in eastern Gambia, $2008-2013$. Pediatr. Infect. Dis. J. 2015, 34, e107-e112. [CrossRef]

98. Hammitt, L.L.; Crane, R.J.; Karani, A.; Mutuku, A.; Morpeth, S.C.; Burbidge, P.; Goldblatt, D.; Kamau, T.; Sharif, S.; Mturi, N.; et al. Effect of Haemophilus influenzae type $\mathrm{b}$ vaccination without a booster dose on invasive $H$ influenzae type $\mathrm{b}$ disease, nasopharyngeal carriage, and population immunity in Kilifi, Kenya: A 15-year regional surveillance study. Lancet. Glob. Health 2016, 4, e185-e194. [CrossRef]

99. Low, N.; Redmond, S.M.; Rutjes, A.W.; Martínez-González, N.A.; Egger, M.; di Nisio, M.; Scott, P. Comparing Haemophilus influenzae type b conjugate vaccine schedules: A systematic review and meta-analysis of vaccine trials. Pediatr. Infect. Dis. J. 2013, 32, 1245-1256. [CrossRef] [PubMed]

100. Mangtani, P.; Mulholland, K.; Madhi, S.A.; Edmond, K.; O’Loughlin, R.; Hajjeh, R. Haemophilus influenzae type b disease in HIVinfected children: A review of the disease epidemiology and effectiveness of Hib conjugate vaccines. Vaccine 2010, 28, 1677-1683. [CrossRef]

101. Tsang, R.S.W.; Ulanova, M. The changing epidemiology of invasive Haemophilus influenzae disease: Emergence and global presence of serotype a strains that may require a new vaccine for control. Vaccine 2017, 35, 4270-4275. [CrossRef]

102. Ladhani, S.N.; Collins, S.; Vickers, A.; Litt, D.J.; Crawford, C.; Ramsay, M.E.; Slack, M.P. Invasive Haemophilus influenzae serotype e and $\mathrm{f}$ disease, England and Wales. Emerg. Infect. Dis. 2012, 18, 725-732. [CrossRef] [PubMed]

103. Ladhani, S.; Slack, M.P.; Heath, P.T.; von Gottberg, A.; Chandra, M.; Ramsay, M.E. Invasive Haemophilus influenzae Disease, Europe, 1996-2006. Emerg. Infect. Dis. 2010, 16, 455-463. [CrossRef]

104. Van Eldere, J.; Slack, M.P.; Ladhani, S.; Cripps, A.W. Non-typeable Haemophilus influenzae, an under-recognised pathogen. Lancet Infect. Dis. 2014, 14, 1281-1292. [CrossRef]

105. Gratten, M.; Barker, J.; Shann, F.; Gerega, G.; Montgomery, J.; Kajoi, M.; Lupiwa, T. Non-type b Haemophilus influenzae meningitis. Lancet 1985, 1, 1343-1344. [CrossRef]

106. Gratten, M.; Montgomery, J. The bacteriology of acute pneumonia and meningitis in children in Papua New Guinea: Assumptions, facts and technical strategies. Papua New Guin. Med. J. 2005, 48, 73-86.

107. Millar, E.V.; O’Brien, K.L.; Watt, J.P.; Lingappa, J.; Pallipamu, R.; Rosenstein, N.; Hu, D.; Reid, R.; Santosham, M. Epidemiology of invasive Haemophilus influenzae type A disease among Navajo and White Mountain Apache children, 1988-2003. Clin. Infect. Dis. Off. Publ. Infect. Dis. Soc. Am. 2005, 40, 823-830. [CrossRef] [PubMed]

108. Tsang, R.S.; Mubareka, S.; Sill, M.L.; Wylie, J.; Skinner, S.; Law, D.K. Invasive Haemophilus influenzae in Manitoba, Canada, in the postvaccination era. J. Clin. Microbiol. 2006, 44, 1530-1535. [CrossRef]

109. Tsang, R.S.; Bruce, M.G.; Lem, M.; Barreto, L.; Ulanova, M. A review of invasive Haemophilus influenzae disease in the Indigenous populations of North America. Epidemiol. Infect. 2014, 142, 1344-1354. [CrossRef]

110. Bruce, M.G.; Deeks, S.L.; Zulz, T.; Navarro, C.; Palacios, C.; Case, C.; Hemsley, C.; Hennessy, T.; Corriveau, A.; Larke, B.; et al. Epidemiology of Haemophilus influenzae serotype a, North American Arctic, 2000-2005. Emerg. Infect. Dis. 2008, 14, 48-55. [CrossRef]

111. McConnell, A.; Tan, B.; Scheifele, D.; Halperin, S.; Vaudry, W.; Law, B.; Embree, J. Invasive infections caused by Haemophilus influenzae serotypes in twelve Canadian IMPACT centers, 1996-2001. Pediatr. Infect. Dis. J. 2007, 26, 1025-1031. [CrossRef] [PubMed]

112. Zwahlen, A.; Kroll, J.S.; Rubin, L.G.; Moxon, E.R. The molecular basis of pathogenicity in Haemophilus influenzae: Comparative virulence of genetically-related capsular transformants and correlation with changes at the capsulation locus cap. Microb. Pathog. 1989, 7, 225-235. [CrossRef]

113. Soeters, H.M.; Blain, A.; Pondo, T.; Doman, B.; Farley, M.M.; Harrison, L.H.; Lynfield, R.; Miller, L.; Petit, S.; Reingold, A.; et al. Current Epidemiology and Trends in Invasive Haemophilus influenzae Disease-United States, 2009-2015. Clin. Infect. Dis. Off. Publ. Infect. Dis. Soc. Am. 2018, 67, 881-889. [CrossRef] [PubMed]

114. Soeters, H.M.; Oliver, S.E.; Plumb, I.D.; Blain, A.E.; Zulz, T.; Simons, B.C.; Barnes, M.; Farley, M.M.; Harrison, L.H.; Lynfield, R.; et al. Epidemiology of Invasive Haemophilus influenzae Serotype a Disease-United States, 2008-2017. Clin. Infect. Dis. Off. Publ. Infect. Dis. Soc. Am. 2020. [CrossRef]

115. Bender, J.M.; Cox, C.M.; Mottice, S.; She, R.C.; Korgenski, K.; Daly, J.A.; Pavia, A.T. Invasive Haemophilus influenzae disease in Utah children: An 11-year population-based study in the era of conjugate vaccine. Clin. Infect. Dis. Off. Publ. Infect. Dis. Soc. Am. 2010, 50, e41-e46. [CrossRef]

116. Crandall, H.; Christiansen, J.; Varghese, A.A.; Russon, A.; Korgenski, E.K.; Bengtson, E.K.; Dickey, M.; Killpack, J.; Knackstedt, E.D.; Daly, J.A.; et al. Clinical and Molecular Epidemiology of Invasive Haemophilus influenzae Serotype a Infections in Utah Children. J. Pediatr. Infect. Dis. 2019, 9, 650-655. [CrossRef] [PubMed] 
117. Antony, S.; Kaushik, A.; Mauriello, C.; Chatterjee, A. Non-Type b Haemophilus influenzae Invasive Infections in North Dakota and South Dakota, 2013-2015. J. Pediatr. Infect. Dis. 2017, 6, 281-284.

118. Ribeiro, G.S.; Lima, J.B.; Reis, J.N.; Gouveia, E.L.; Cordeiro, S.M.; Lobo, T.S.; Pinheiro, R.M.; Ribeiro, C.T.; Neves, A.B.; Salgado, K.; et al. Haemophilus influenzae meningitis 5 years after introduction of the Haemophilus influenzae type b conjugate vaccine in Brazil. Vaccine 2007, 25, 4420-4428. [CrossRef]

119. Zanella, R.C.; Bokermann, S.; Andrade, A.L.; Flannery, B.; Brandileone, M.C. Changes in serotype distribution of Haemophilus influenzae meningitis isolates identified through laboratory-based surveillance following routine childhood vaccination against $H$. influenzae type b in Brazil. Vaccine 2011, 29, 8937-8942. [CrossRef] [PubMed]

120. Lima, J.B.; Ribeiro, G.S.; Cordeiro, S.M.; Gouveia, E.L.; Salgado, K.; Spratt, B.G.; Godoy, D.; Reis, M.G.; Ko, A.I.; Reis, J.N. Poor clinical outcome for meningitis caused by Haemophilus influenzae serotype a strains containing the IS1016-bexA deletion. J. Infect. Dis. 2010, 202, 1577-1584. [CrossRef] [PubMed]

121. Giufrè, M.; Cardines, R.; Brigante, G.; Orecchioni, F.; Cerquetti, M. Emergence of Invasive Haemophilus influenzae type a Disease in Italy. Clin. Infect. Dis. Off. Publ. Infect. Dis. Soc. Am. 2017, 64, 1626-1628. [CrossRef]

122. Collins, S.; Fry, N.K.; Ladhani, S.N.; Litt, D. The rise (and fall) of invasive Haemophilus influenzae serotype a (Hia) disease in England )C-(EMGM2019-13311). In Proceedings of the 15th EMGM Congress, Lisbon, Portugal, 27-30 May 2019; Available online: https://emgm.eu/meetings/emgm2019/emgm2019_abstracts.pdf (accessed on 6 April 2021).

123. Roaa, Z.; Abdulsalam, A.; Shahid, G.; Kamaldeen, B.; Tariq, A.F. Pediatric invasive disease due to Haemophilus influenzae serogroup a in Riyadh, Saudi Arabia: Case series. J. Infect. Dev. Ctries 2016, 10, 528-532. [CrossRef] [PubMed]

124. Cox, A.D.; Barreto, L.; Ulanova, M.; Bruce, M.G.; Tsang, R. Developing a vaccine for Haemophilus influenzae serotype a: Proceedings of a workshop. Can. Commun. Dis. Rep. 2017, 43, 89-95. [CrossRef] [PubMed]

125. Whittaker, R.; Economopoulou, A.; Dias, J.G.; Bancroft, E.; Ramliden, M.; Celentano, L.P. Epidemiology of Invasive Haemophilus influenzae Disease, Europe, 2007-2014. Emerg. Infect. Dis. 2017, 23, 396-404. [CrossRef]

126. Takla, A.; Schönfeld, V.; Claus, H.; Krone, M.; An der Heiden, M.; Koch, J.; Vogel, U.; Wichmann, O.; Lâm, T.-T. Invasive Haemophilus influenzae Infections in Germany After the Introduction of Routine Childhood Immunization, 2001-2016. Open Forum Infect. Dis. 2020, 7, ofaa444. [CrossRef]

127. Urwin, G.; Krohn, J.A.; Deaver-Robinson, K.; Wenger, J.D.; Farley, M.M. Invasive disease due to Haemophilus influenzae serotype f: Clinical and epidemiologic characteristics in the H. influenzae serotype b vaccine era. The Haemophilus influenzae Study Group. Clin. Infect. Dis. Off. Publ. Infect. Dis. Soc. Am. 1996, 22, 1069-1076. [CrossRef]

128. MacNeil, J.R.; Cohn, A.C.; Farley, M.; Mair, R.; Baumbach, J.; Bennett, N.; Gershman, K.; Harrison, L.H.; Lynfield, R.; Petit, S.; et al Current epidemiology and trends in invasive Haemophilus influenzae disease-United States, 1989-2008. Clin. Infect. Dis. Off. Publ. Infect. Dis. Soc. Am. 2011, 53, 1230-1236. [CrossRef]

129. Abou-Hanna, J.; Panning, K.; Mehta, H. Haemophilus influenzae Type f Meningitis Complicated by Bilateral Subdural Empyema, Central Venous Thrombosis, and Bilateral Sensorineural Hearing Loss in an Immunocompetent 12-month-old. Cureus 2019, 11, e4850. [CrossRef] [PubMed]

130. Resman, F.; Ristovski, M.; Ahl, J.; Forsgren, A.; Gilsdorf, J.R.; Jasir, A.; Kaijser, B.; Kronvall, G.; Riesbeck, K. Invasive disease caused by Haemophilus influenzae in Sweden 1997-2009; evidence of increasing incidence and clinical burden of non-type b strains. Clin. Microbiol. Infect. Off. Publ. Eur. Soc. Clin. Microbiol. Infect. Dis. 2011, 17, 1638-1645. [CrossRef] [PubMed]

131. Collins, S.; Vickers, A.; Ladhani, S.N.; Flynn, S.; Platt, S.; Ramsay, M.E.; Litt, D.J.; Slack, M.P. Clinical and Molecular Epidemiology of Childhood Invasive Nontypeable Haemophilus influenzae Disease in England and Wales. Pediatr. Infect. Dis. J. 2016, 35, e76-e84. [CrossRef] [PubMed]

132. Ulu-Kilic, A.; Altay, F.A.; Gürbüz, Y.; Otgun, S.N.; Sencan, I. Haemophilus influenzae serotype e meningitis in an adult. J. Infect. Dev. Ctries 2010, 4, 253-255. [CrossRef]

133. Gkentzi, D.; Slack, M.P.; Ladhani, S.N. The burden of nonencapsulated Haemophilus influenzae in children and potential for prevention. Curr. Opin. Infect. Dis. 2012, 25, 266-272. [CrossRef]

134. Van Wessel, K.; Rodenburg, G.D.; Veenhoven, R.H.; Spanjaard, L.; van der Ende, A.; Sanders, E.A. Nontypeable Haemophilus influenzae invasive disease in The Netherlands: A retrospective surveillance study 2001-2008. Clin. Infect. Dis. Off. Publ. Infect. Dis. Soc. Am. 2011, 53, e1-e7. [CrossRef] [PubMed]

135. Cardines, R.; Giufre, M.; Mastrantonio, P.; Ciofi degli Atti, M.L.; Cerquetti, M. Nontypeable Haemophilus influenzae meningitis in children: Phenotypic and genotypic characterization of isolates. Pediatr. Infect. Dis. J. 2007, 26, 577-582. [CrossRef]

136. Kalies, H.; Siedler, A.; Grondahl, B.; Grote, V.; Milde-Busch, A.; von Kries, R. Invasive Haemophilus influenzae infections in Germany: Impact of non-type b serotypes in the post-vaccine era. BMC Infect. Dis. 2009, 9, 45. [CrossRef] [PubMed]

137. Sarangi, J.; Cartwright, K.; Stuart, J.; Brookes, S.; Morris, R.; Slack, M. Invasive Haemophilus influenzae disease in adults. Epidemiol. Infect. 2000, 124, 441-447. [CrossRef] [PubMed]

138. Dworkin, M.S.; Park, L.; Borchardt, S.M. The changing epidemiology of invasive Haemophilus influenzae disease, especially in persons $\geq 65$ years old. Clin. Infect. Dis. Off. Publ. Infect. Dis. Soc. Am. 2007, 44, 810-816. [CrossRef]

139. Desai, S.; Jamieson, F.B.; Patel, S.N.; Seo, C.Y.; Dang, V.; Fediurek, J.; Navaranjan, D.; Deeks, S.L. The Epidemiology of Invasive Haemophilus influenzae Non-Serotype b Disease in Ontario, Canada from 2004 to 2013. PLoS ONE 2015, 10, e0142179. [CrossRef]

140. Slack, M.; Esposito, S.; Haas, H.; Mihalyi, A.; Nissen, M.; Mukherjee, P.; Harrington, L. Haemophilus influenzae type b disease in the era of conjugate vaccines: Critical factors for successful eradication. Exp. Rev. Vaccines 2020, 19, 903-917. [CrossRef] 